\title{
Doses de humor e realidade
}

\section{Maria Luísa Fontenele}

\section{de Paula}

Mestranda em Comunicação e Inovação pela Universidade Municipal de São Caetano do Sul (USCS).

luisafontenele@hotmail.com

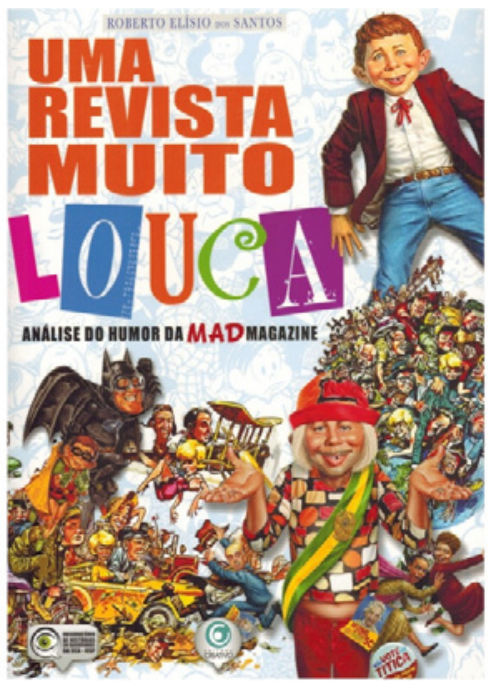

Uma revista muito louca - análise do humor da Mad Magazine, do prof. dr. Roberto Elísio dos Santos, lançado em 2015 pela editora Criativo, resultou de seu trabalho de pesquisa para obtenção do ítulo de Livre Docente em Comunicação pelo Departamento de Jornalismo e Editoração da Escola de Comunicação e Artes da Universidade de São Paulo. Já na introdução, o autor esclarece que seu primeiro contato com a revista em análise se deu no início de sua adolescência. Desde então, o periódico somou-se a outros que passaram a compor o repertório de suas leituras em quadrinhos. E, de um simples prazer, o gosto por esse tipo de literatura se transformou em especialização em sua área de atuação acadêmica.

O livro em análise é composto por cinco capítulos. O primeiro, "Humor na veia jugular", traça um retrospecto didático-conceitual das origens do humor, sua aplicação prática em diversas artes, em especial nos quadrinhos. Nesse capítulo, destacam-se os estudos de diversos autores, de Aristóteles a Propp, que buscaram reconhecer no humor uma espécie de linguagem que comunica para muito além do riso. Das várias atividades artísticas já contaminadas pelo humor, que se difunde pelos meios de comunicação de massa, fica-se sabendo que a arte em quadrinhos surgiu em 1731, quando William Hogarth desenha uma sequência de seis painéis, com algumas frases na parte inferior dos desenhos, para a imprensa britânica. Surgem os "quadrinhos", que inicialmente procuravam abordar temas clássicos, de cunho moralista.

O segundo capítulo, "Por favor, compre esta revista", delineia a espécie artística "quadrinhos", cujo surgimento e expansão se devem ao desenvolvimento da própria imprensa em meados do século XVIII. Os quadrinhos, inclusive, passaram a ser um atrativo a mais para expandir a venda de jornais. Para tanto, passaram a circular encartes com histórias inéditas. Somente no final do século XIX, contudo, lança-se nos Estados Unidos 
o primeiro formato que deu origem aos quadrinhos: The Yellow Kid Magazine. Na década de 1930, apesar dos efeitos da Grande Depressão, havia revistas com personagens dos mais variados tipos, inclusive no formato em cores. No período da Segunda Guerra, inclusive, os grandes heróis foram usados para ressaltar o poder e o patriotismo americanos.

Para concorrer com outros veículos de comunicação de massa, o mercado editorial quadrinista apela para vários formatos e gêneros, pois "terror" e "crime" levaram à paralização de alguns títulos. Com o propósito de usar como base editorial o humor, em 1952 a Mad é lançada.

No terceiro capítulo, "Os mesmos idiotas de sempre", apresentam-se os principais criadores de histórias em quadrinhos e suas respectivas editoras. Em especial, Harvey Kurtzman que, após largar o exército, iniciou a carreira como quadrinista, inclusive no que depois viria a ser a Marvel Comics. Kurtzman, cansado da temática "guerra", sugere ao publisher da EC um novo título que lhe possibilitasse criar livremente, sem a necessidade de tantas pesquisas. Surge a Mad, cujo propósito é "fazer rir".

Com a saída de Kurtzman, novos artistas passam a contribuir para a criação de vários personagens na Mad. Contudo, o personagem Alfred E. Neuman foi seu principal destaque, tornando-se mascote da revista e sendo reproduzido diversas vezes, independente da temática proposta.

O quarto capítulo, “O quê, me preocupar?", passa a analisar as várias formas de humor da revista $\mathrm{Mad}$, a partir dos elementos verbais e pictóricos, além dos recursos humorísticos, tais como a sátira comportamental e política. Observa-se a mascote Alfred se transformar nas mais variadas personalidades, de Obama a Amy Winehouse, de Harry Potter a Minions, sempre com frases de efeito ou de duplo sentido. Todas as edições da revista são um retrato do tempo. A mascote se transforma em todas as personagens possíveis, basta que elas estejam em evidência.

No entanto, a revista não descuida de heróis, anti-heróis e super-heróis atuais e do passado. Em quase todas as edições, a revista traz situações inusitadas envolvendo algumas dessas personagens famosas de quadrinhos (Recruta Zero, Garfield, Popeye, Pato Donald etc.): como seriam quando crianças, ou adultos, se crianças; como agiriam em outros períodos históricos, convivendo com personalidades de outras épocas; invadindo outras histórias em quadrinhos; simulando troca de casais famosos dos quadrinhos; misturando histórias em quadrinhos com personagens de filmes famosos ou personalidades do mundo real etc.

Nos últimos tempos, a inovação fica por conta das paródias dos seriados, artigos publicitários ou qualquer evento, seja artístico ou não, desde que possa ser utilizado como referencial de criação a partir das propostas da revista. 
Os quadrinhos são a base da revista, que encontrou na paródia verbal ou pictórica uma forma de ampliar seu elenco e inovar sempre seus roteiros, já que não dispõe de muitos personagens. Ao contrário, apropria-se das histórias e personagens já existentes para dar muitas e risíveis versões a elas.

Nessa jornada criativa, há espaço para fazer paródia em episódios inusitados sobre anatomia (estudo do corpo humano com base em alguns personagens, como o Popeye, por exemplo); sobre filmes ganhadores do Oscar (com finais diferentes ou esperados pelo público); sobre o encontro de personagens de filmes diversos.

No quinto capítulo "Mad in Brasil", ficamos sabendo que, antes de sua primeira edição brasileira, em julho de 1974, o escritor e cartunista Ziraldo conseguira publicar uma arte na revista americana em 1967. Por ter ganhado uma viagem aos Estados Unidos durante um concurso, Ziraldo aproveitou a oportunidade para apresentar e vender alguns de seus desenhos à revista.

Mesmo com a mudança de editoras, a Mad no Brasil conseguiu a proeza de ser publicada mensalmente, enquanto nos Estados Unidos era publicada apenas oito vezes por ano.

Embora os artistas produtores fossem nacionais, a proposta da revista continuava a mesma: fazer rir. As paródias obedeciam quase aos mesmos critérios já citados, porém com personagens também nacionais e conhecidas do grande público.

A sátira a muitas personagens e personalidades da cultura brasileira passou pelas páginas da $\mathrm{Mad}$. Somente durante o período ditatorial a revista visou mais os defeitos físicos que a atuação política das personalidades. Atualmente, contudo, desde que se esteja em evidência, corre-se o risco de estampar as páginas da $\mathrm{Mad}$.

$\mathrm{Na}$ "Conclusão" o autor entende haver poucas diferenças entre a edição estadunidense e a brasileira, pois ambas seguem as mesmas características gráficas, verbais, e o mesmo estilo de humor, uso de paródias etc. A distinção reside basicamente na inserção de personagens e personalidades da cultura e sociedade brasileira. Para o autor, nada é sagrado para a Mad, mas tudo é sempre inovador. E, com muitas doses de humor, a revista tem exercido um papel na crítica e consciência da sociedade, em vários momentos da história. Seja aqui ou onde ela for editada.

SANTOS, R. E. Uma revista muito louca - análise do humor da Mad Magazine. 1. ed. São Paulo: Criativo, 2015. 